\title{
Social and healthcare staff's self-reported simulation learning needs in small and middle-sized enterprises
}

\author{
Mari Salminen-Tuomaala*1, Elina Kangasluoma ${ }^{1}$, Asta Niinimäki ${ }^{1}$, Marja-Terttu Kurunsaari ${ }^{2}$ \\ ${ }^{1}$ Seinäjoki University of Applied Sciences, School of Health Care and Social Work, Finland \\ ${ }^{2}$ Seinäjoki Vocational Education Centre, Seinäjoki, Finland
}

Received: February 13, 2018

DOI: $10.5430 /$ cns.v6n3p46
Accepted: March 20, 2018

Online Published: March 26, 2018

\begin{abstract}
Objective: The study describes learning needs of social and healthcare staff in small and middle-sized enterprises, which participate in a simulation-based coaching project. The study aims at producing knowledge that can be used to develop the content of multiprofessional simulation-based coaching.

Methods: Data were collected through an online survey using a questionnaire with quantitative and qualitative items. The qualitative data were analyzed using inductive content analysis and the statistical data using SPSS for Windows version 23.

Results: The professional development needs of social and healthcare staff in small and middle-sized enterprises emerged in the following areas: the respondent's professional knowledge base; the respondent's professional skill base; multiprofessional collaboration; development of the business, and networking between enterprises. The staff recognized their need to develop both personally in the area of key competences, and collaboratively in the organization.

Conclusions: The results will be used when planning multiprofessional simulation-based coaching for acute, recurrent and infrequent situations in small and middle-sized social and healthcare enterprises. Simulation pedagogy can also be used to prepare for various client and family counseling situations and to practice communication and interaction for interdisciplinary teamwork.
\end{abstract}

Key Words: Simulation coaching, Simulation training, Professional development, Multiprofessional

\section{INTRODUCTION}

Several national and international programs and guidelines aim at improving the quality and effectiveness of healthcare services. For example, the ongoing third Health Program of the European Union for the period 2014-2020 stresses the development of innovative and sustainable health services and access to better and safer health care. ${ }^{[1]}$ In Finland, where this study was conducted, a current quality recommendation emphasizes a good quality of life for older people, including timely services based on needs assessment and adequate staffing and competence levels. ${ }^{[2]}$ The Ministry of Economic
Affairs and Employment in Finland boosts the development of health care business and the availability of competent staff by a strategic program introduced in $2011 .^{[3]}$

The multiprofessional project discussed in this paper is an example of the current efforts to meet these challenges. A university of applied sciences, a vocational education center and a health technology development center have joined forces to establish a research and development project, whose purpose is to develop simulation-based education for small and middle-sized enterprises (SMEs) in the health and social welfare sector. The project received funding from the Euro-

\footnotetext{
*Correspondence: Mari Salminen-Tuomaala; Email: Mari.Salminen-Tuomaala@seamk.fi; Address: Seinäjoki University of Applied Sciences, School of Health Care and Social Work, Finland.
} 
pean Social Fund (ESF) for 1 August 2017 - 31 December 2019. The aim is to create a package of simulation-based training for 20 regional enterprises, starting with the staff's learning needs. The enterprises involved in the project offer child protection services, as well as support, care, rehabilitation and residential services for people with intellectual disabilities and mental health problems.

The simulation-based coaching or training described in this paper will be tailored for the needs of the enterprises. The project partners use the term coaching to signal a more equal relationship between the coach or facilitator and the participants than is usually the case in traditional teaching. The project is a new kind of undertaking both regionally and nationally. The training will be based on the participants' self-reported learning needs and organized in real-life settings and in simulated learning environments provided by the project partners. This arrangement will facilitate participation of several staff members simultaneously. The project is expected to bring about new insights and innovations, for example new service and action models.

\section{Background}

Social and healthcare staff are increasingly expected to possess a wide set of skills, even in small and middle-sized enterprises having less than 250 persons employed and an annual turnover below 50 million euros. ${ }^{[4]}$ In Finland, the SMEs play a significant role in economy; $65 \%$ of all private-sector employees work in SMEs, which generate approximately $50 \%$ of the combined turnover of all Finnish businesses. ${ }^{[5]}$ In the health and welfare sector, however, the current trend is that large companies seek to buy out smaller ones. The project described in this paper is an example of a contrasting approach, as it represents efforts to make SMEs more attractive to employees and clients. Staff's theoretical and practical competence is an important basis for competitiveness in the small and middle-sized health and welfare companies, which provide support, care, rehabilitation, therapy and residential services. Their clients are older citizens, people with mental health problems and children and young people in need of substitute care.

In Finland, the situation of SMEs is affected by the rapidly aging population and by an extensive reform of the health and social services, which has been under preparation for years. Earlier practices fail to be effective for an increasing number of clients with multiple health and social problems and deteriorated functional capacity. Multiprofessional collaboration and competence are required to address the great variety of problems ${ }^{[6,7]}$ and to provide more comprensive care and services. This entails that various professional groups must learn to interact and share knowledge, skills and responsibilities. ${ }^{[8]}$ In addition, digital information and communication technology have become an important component of the competence expected from staff in health and social services. ${ }^{[9]}$

Competence and related topics are often addressed in international research using overlapping and ambiguous concepts. This is true of Finland as well. Competence has been defined as a state of being able and qualified to perform certain tasks, whereas qualification has been seen as a set of official requirements that employers expect from their workers. Professional skills and knowledge or knowhow can be said to be closely connected to both competence and qualifications in that they represent capability required by qualifications and enabled by competence. ${ }^{[10]}$ It has also been suggested that profession-specific knowledge and skills on one hand, and personality characteristics molded by the person's social environment on the other hand, are combined to create the know-how required in practicing a profession. These skills and knowledge are dynamic and actively constructed in a social context through formal education and informal experience and development. Professionals can be said to aim at successful application of knowledge to reach certain objectives. ${ }^{[11]}$ In the context of health and social services, professional competence and clinical expertise are nowadays associated with the requirements of evidence-based practice, client safety, promotion of health and functional capacity and client-centered multiprofessional practice. ${ }^{[12]}$

It has been proposed that to meet these challenges, both individual and collective learning in a context are required. In other words, collaborative and contextual learning could take place in the person's working community, ${ }^{[11]}$ which in this project is a small or middle-sized enterprise in the health or social sector. Such learning and professional development can be described in terms of hybrid knowledge or hybrid expertise building. The terms refer to expertise created in intensive interaction, with individuals crossing borders together. ${ }^{[13]}$

The choice of learning environments and pedagogical methods is essential for successful professional development programs. Multiprofessional simulation-based training can create a fruitful setting for learning experiences described above. Simulation is an example of action-based learning, and it has been found suitable for promoting interaction, collaboration and teamwork skills of practicing professionals. ${ }^{[14-16]}$ Learning in multiprofessional small groups can promote participants' understanding of various professional roles and tasks. ${ }^{[17,18]}$ It can also facilitate the creation of networks and sharing of good practices. Ideally, it means an evolving partnership, which will create added value through networking 
and collective learning and development. ${ }^{[11]}$

Simulation-based training should start from the participants' explicit learning needs and aim at imitating reality in as genuine a context as possible. Simulation is a holistic and experiential way of learning and it can be used to the develop a wide variety of competences. ${ }^{[19]}$ Simulation can increase staff's confidence in their technical and non-technical skills ${ }^{[20-22]}$ and their situational sensitivity, emotional intelligence and problem-solving skills, all essential in securing patient safety and in preventing near misses in patient care. ${ }^{[23-26]}$

Training based on simulation is suitable for practicing both acute, recurrent and infrequent situations in patient or client care. Provided that an encouraging learning atmosphere is maintained, simulation can be useful in increasing empathy, or the ability to place oneself in another person's position. ${ }^{[27]}$ Provision of positive learning experiences is essential, ${ }^{[22]}$ as appreciation expressed by facilitators and peers can enhance participants' self-confidence and preparedness to work in multiprofessional teams. ${ }^{[22,28]}$ Feedback discussions following simulated sessions have also been found helpful in creating a shared understanding of the challenges and potential solutions related to the situation at hand. ${ }^{[18]}$

\section{MethodS}

The purpose of this study was to describe social and healthcare staff's learning needs in small and middle-sized enterprises, which take part in a simulation-based learning project. The study aims at producing knowledge that can be used to develop the content of a multiprofessional simulation training program. Quantitative and qualitative data were collected from SME staff members using a survey. The quantitative part of the study, whose results will be reported in another study, functioned as a self-assessment of the staff's competences. This article concentrates on the qualitative data. The statistical results are discussed only as far as they are relevant to the qualitative analysis.

The research question was: What are the learning needs of social and healthcare staff in small and middle-sized enterprises?

\subsection{Target group and data collection}

Participants were staff members in 20 small and middle-sized social and healthcare enterprises in Finland. Most of them were practical nurses with a vocational qualification, or held a Bachelor's degree or equivalent in nursing, public health nursing, social services, elderly care or physiotherapy.

Data were collected between October 1 and December 1 in 2017. The Webropol online survey tool was selected, because it allowed easy data collection using an electronic questionnaire. The questionnaire was pre-tested by project partners $(n=10)$, project steer group members $(n=2)$ and representatives of small and middle-sized enterprises $(n=$ 2). Two background questions were added following the test. In other respects, the questionnaire was deemed clear and appropriate for data collection.

The target group members were informed of the study through the Moodle learning platform, used for project communication. In addition, potential respondents received information, an invitation and a link to the survey through their personal email. The message emphasized the voluntary nature of participation and respondents' anonymity throughout the study. The managers in the enterprises were asked to encourage their staff to participate in the study. The Webropol tool proved effective; the results were available fast and they could be easily imported into Excel and then into SPSS. ${ }^{[29]}$

The questionnaire, which was based on a systematic literature review and on a competence survey carried out in small and middle-sized enterprises in spring 2017, consisted of both quantitative $(n=44)$ and qualitative items $(n=4)$. The survey also contained background questions about the sex, age, education and occupation of the respondent. In the quantitative part, respondents were asked to rate their interaction skills and theoretical and practical competences in various areas of professional practice.

This article mainly deals with the results of the qualitative data analysis. The respondents answered the following questions: (1) What kind of learning needs do you have? (2) What kind of skills would you like to learn during this simulation coaching project? (3) What kind of simulation-based training do you need most? (4) What kind of co-operative simulation training is needed in your enterprise?

\subsection{Data analysis}

The quantitative data were analyzed using SPSS for Windows 23. Respondents had rated their competences using a Likert scale (1 very good; 2 rather good; 3 neither good nor poor; 4 rather poor and 5 , very poor). They were divided into categories according to age, sex and educational background to facilitate comparison between variables, conducted using the Mann-Whitney $U$ test. The results were given in frequencies, percentages and means.

The qualitative data were analyzed using inductive content analysis. The analysis was conducted by one of the investigators, but all the authors contributed by commenting on the results of the analysis. ${ }^{[30]}$

Table 1 shows an example of how the qualitative analysis proceeded. First, the material was read through several times. Sentences and other units that represented a reply to a ques- 
tion were picked out into a Word file. They were then rewritten as reduced expressions, while taking care that the original core idea was retained. Expressions with similar content were grouped under categories, which were provided with expressive names. These categories were then combined to form higher order categories, which were finally collapsed into a main category. The investigator returned to the original material repeatedly during the process to make sure that the interpretation was plausible.

Table 1. Example of the inductive content analysis

\begin{tabular}{|c|c|c|c|}
\hline Original expression & Reduced expression & Sub-category & Category \\
\hline $\begin{array}{l}\text { To understand the connection between } \\
\text { research knowledge and practice in a } \\
\text { deeper way } \\
\text { - Knowing how to use evidence- based } \\
\text { knowledge in your work }\end{array}$ & $\begin{array}{l}\text { Making use of research } \\
\text { knowledge in clinical work } \\
\text { - Application of evidence-based } \\
\text { knowledge in clinical work }\end{array}$ & $\begin{array}{l}\text { - Use of scientific } \\
\text { knowledge at work }\end{array}$ & \\
\hline $\begin{array}{l}\text { - New knowledge about the effects and } \\
\text { combined effects of medicines } \\
\text { - Monitoring and recognizing effects and } \\
\text { side effects of psychiatric drugs }\end{array}$ & $\begin{array}{l}\text { - Updating knowledge about } \\
\text { medication } \\
\text { - Developing monitoring skills for } \\
\text { drug care }\end{array}$ & $\begin{array}{l}\text { - Medication } \\
\text { administration }\end{array}$ & $\begin{array}{l}\text { - Respondent's } \\
\text { professional } \\
\text { knowledge base }\end{array}$ \\
\hline $\begin{array}{l}\text { - New research knowledge about chronic } \\
\text { diseases and self-care guidance } \\
\text { - Knowledge about acute situations, how to } \\
\text { act in them }\end{array}$ & $\begin{array}{l}\text { - Updating knowledge about } \\
\text { chronic diseases } \\
\text { - Updating protocols for acute } \\
\text { situations }\end{array}$ & $\begin{array}{l}\text { - Competence in } \\
\text { acute and prolonged } \\
\text { care situations }\end{array}$ & \\
\hline
\end{tabular}

\subsection{Research ethics and trustworthiness}

The topic was selected because simulation-based education is much discussed but there is still relatively little research on it in Finland, and up until now, no studies have been conducted from the perspective of small and middle-sized enterprises.

Good scientific practice and research ethical principles were observed ${ }^{[31]}$ Anonymity and the voluntary nature of participation were stressed on the project's Moodle website and in the emails sent to potential participants. In the questionnaire, respondents were not asked to disclose which organization they represented. ${ }^{[32]}$

The trustworthiness of the study was evaluated using the criteria of credibility, reflexivity, confirmability and transferability. ${ }^{[33]}$ The credibility was enhanced by a suitable data collection method, ${ }^{[30]}$ the Webropol survey, which ensured that essential topics could be included effectively. The participants' responses to the four open questions were found to provide knowledge of their genuinely experienced learning needs for multiprofessional simulated learning. The high response rate (96\%) increased the trustworthiness of the research. ${ }^{[34]}$

Reflexivity means the investigators' awareness of their role and its effect on the analysis. ${ }^{[30]}$ The members of the research group in this study had some experience of simulation pedagogy, which gave them a preunderstanding of the phenomena to be studied. An effort was made to combine this with an openness to new aspects in the data, allowing the data to "speak". The researchers' prior knowledge of the topic facilitated the analysis, but special attention was paid to keeping the analysis grounded on the data. ${ }^{[35]}$

The data were carefully analyzed and reported with illustrative tables and respondents' original expressions to increase the confirmability of the results. The investigators also reflected on the transferability or generalizability of the results to other settings. ${ }^{[30]}$

\section{Results}

The study had a response rate of $96 \%(n=125)$. Table 2 shows the demographic data for the respondents. Their age varied between 23 and 64 years. The majority of the respondents $(84 \%)$ were women, which is a typical gender ratio in the nursing profession in Finland. Most respondents or 91\% had a vocational or professional education. Practical nurse qualification was the most common (47\%) type of education. The majority of the participants had a social or healthcare qualification, while $8 \%$ represented other fields, for example hospitality, textiles or technology.

The statistical analysis revealed that most respondents rated their theoretical competence as very good in the identification of client's care needs (86\%) and in self-care support to clients with long-term health problems (59\%). However, only $9 \%$ of the staff found that their theoretical competence 
was very good in the area of acute illness and (40\%) agreed that their practical competence in acute situations was rather poor. In the area of practical competence, the analysis further revealed that respondents felt that they had rather good $(68 \%)$ or good $(10 \%)$ skills in choosing appropriate interventions to help their clients.

Table 2. Demographic data on respondents

\begin{tabular}{|c|c|c|}
\hline Respondents & $\mathbf{n}$ & $\%$ \\
\hline \multicolumn{3}{|l|}{ Age } \\
\hline - under 40 years & 40 & 32 \\
\hline - 40-49 years & 37 & 30 \\
\hline - 50 or above & 44 & 35 \\
\hline \multicolumn{3}{|l|}{ Sex } \\
\hline - female & 104 & 84 \\
\hline - male & 19 & 15 \\
\hline \multicolumn{3}{|l|}{ Education } \\
\hline - General secondary education & 11 & 9 \\
\hline - Vocational qualification & 37 & 30 \\
\hline - Professional college level qualification & 40 & 32 \\
\hline - University of Applied Sciences or university & 35 & 28 \\
\hline \multicolumn{3}{|l|}{ Occupation } \\
\hline - Nurse & 19 & 15 \\
\hline - Public health nurse & 7 & 6 \\
\hline - Practical nurse & 59 & 47 \\
\hline - Elderly care expert & 3 & 3 \\
\hline - Social worker & 19 & 15 \\
\hline - Other & 23 & 14 \\
\hline
\end{tabular}

Respondents rated their interaction skills as very good (36\%) or good $(55 \%)$ and their team and group work skills as very good $(36 \%)$ or rather good $(59 \%)$. Despite this, $29 \%$ of the respondents found that their skills in identifying group dynamic factors were very poor and only $18 \%$ rated their skills as very good.

According to the results, simulation training for health and social care staff in small and middle-sized enterprises should be based on professional development needs (main category) The five categories and 18 sub-categories are shown in Table 3. Respondents' development needs emerged in five areas labeled as follows: the respondent's professional knowledge base; the respondent's professional skill base; multiprofessional collaboration; development of the business, and networking between enterprises. In other words, the staff in small and middle-sized enterprises recognized their need to develop both personally in the area of key competences, and collaboratively in the organization. Better collaboration, general development of the business and networking with other enterprises were emphasized.

\subsection{Respondent's professional knowledge base}

The respondents, 125 social and healthcare staff members in small and middle-sized enterprises, felt that they should strengthen their knowledge in the following areas: use of scientific knowledge at work; medication administration, and competence in acute and prolonged care situations.

Use of scientific knowledge at work here refers to the use and application of evidence-based research knowledge in clinical work. Respondents felt that to be able to consider their work of high quality, their everyday decisions should be increasingly based on research evidence. They also found that this would strengthen clients' and families' trust in the staff's competence and in the enterprise in general. The following quote illustrates this thinking:

"I would like to have new knowledge. You get little information about new care options in this company, compared to the hospital world. We easily stick to the same routines and do not have courage to try out new care options. Still, we should develop our enterprise and take responsibility so that clients get the best care from us. We need evidence-based knowledge, so we can explain our decisions. People do not appreciate it if you just say you have a gut feeling about something."

Learning to seek and apply evidence-based knowledge was considered important. It could, according to the respondents, also have a role in improving motivation and coping at work, and in the overall development of the work community. As one respondent put it,

"Evidence-based knowledge, and new options along with it, so you can develop your work, bring your competence to a new level and that way keep up the motivation."

Medication administration was mentioned as an important learning need. Care providers are responsible for safe administration of medicines and they should be able to recognize the desired, side and combined effects of various medicines. Respondents reported that simulation training was required especially pertaining to the medication for psychiatric, older and intellectually disabled clients. They pointed out that they as care providers had a great responsibility for clients' medication, because no doctors were continuously present in small and middle-sized enterprises. Staff members were required to stay alert and watch out for unexpected symptoms or problems that might have been caused by medicines. Respondents said, for example:

"Monitoring and recognizing the effects and side effects of psychiatric drugs.”

"When should you suspect that the confusion might be caused by medicines." 
Table 3. Respondents' professional learning needs

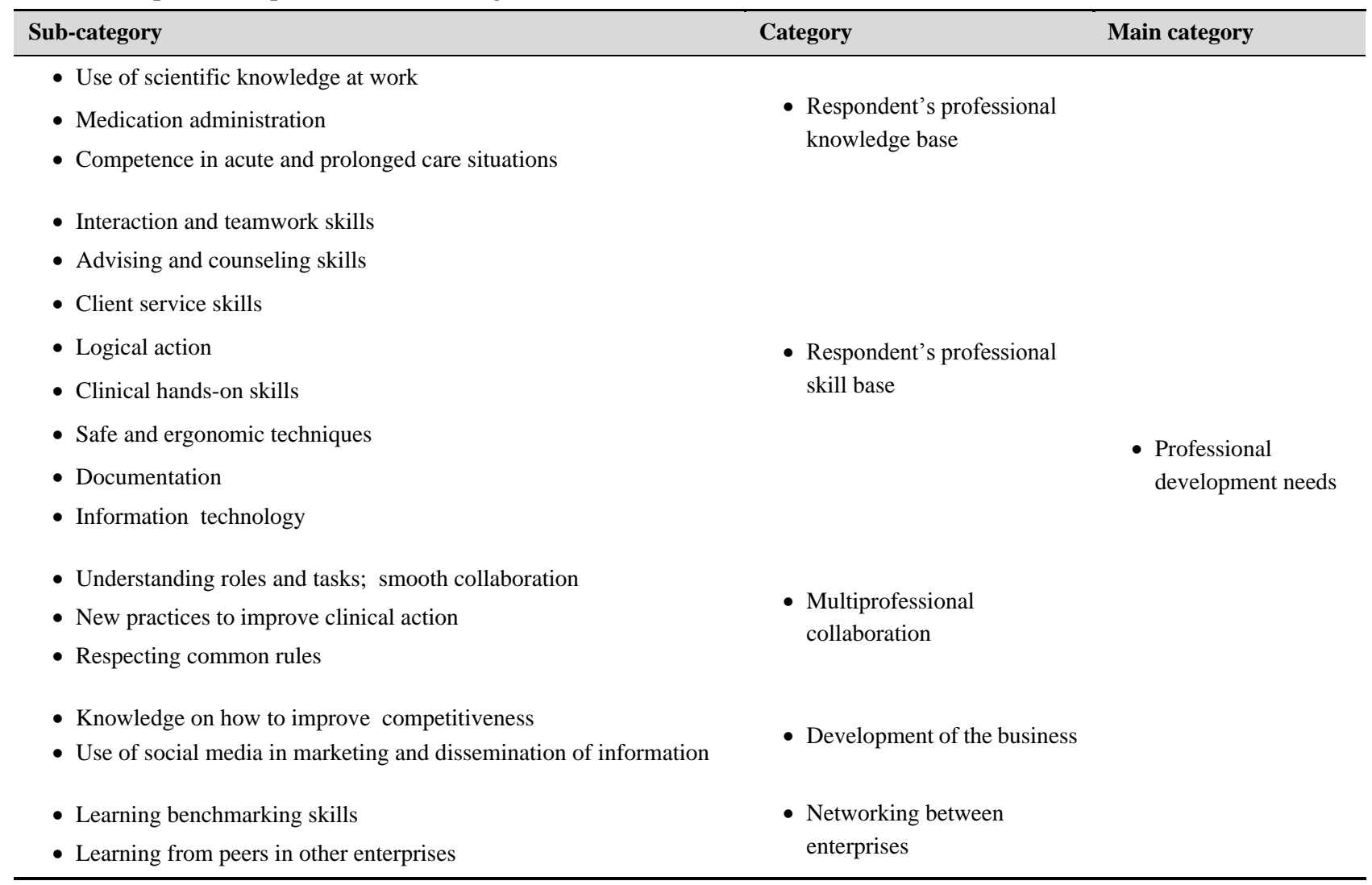

In addition, respondents said that they required more knowledge about medication for acute situations, and suggested simulations to practice recognizing the effects of various medicines. They wished for information on which medicines required that the patient's blood pressure, pulse or blood sugar should be observed after administering the dose. In their own words:

"Monitoring the medication; challenging situations as scenarios, for example how to deal with acute shortness of breath or chest pain."

"A client's blood sugar rocketed and he was thirsty and drowsy, because we did not know that one should monitor the blood sugar if the patient was prescribed a lot of cortisone. The client survived but needed insulin."

Respondents further said that they needed to enhance their competence in acute and prolonged care situations. Acute situations were found particularly challenging, because they were relatively infrequent. Staff members wished for simulated scenarios where they could practice procedures or protocols related to the care of older clients, to be able to deal with chest pain, arrhythmia, dyspnea and unconsciousness, for example. The following quotes illustrate this category of responses:
"Simulation is needed to learn to help old people with chest pain."

"We should practice CPR.”

"Basic acute situations in the care of old people. Observing for changes in their condition, what to take into consideration, how to act."

Further learning needs concerned the management of psychiatric patients' aggressive behavior; the medication and special diets for prolonged illness, and the changing needs for care and support in patients with advanced dementia or in aging clients with intellectual disability. The possibility of using simulated scenarios to prepare for a resident's end-of-life care was also mentioned. To quote the respondents:

"It would be useful to practice end-of-life care with help of scenarios."

"Simulation could be used to enter the experiential world of a dementia client, and to study the perspective of the family member."

"Encountering and supporting people with memory disorders - developing emotional intelligence.” 


\subsection{Respondent's professional skill base}

When enquired about their various skills, respondents recognized personal learning needs in the following areas: interaction and teamwork skills; advising and counseling skills; client service skills; logical action; clinical hands-on skills; safe and ergonomic techniques; documentation, and information technology skills.

Respondents reported a need to learn constructive interaction and teamwork skills, since conflicts were not uncommon among staff at their workplaces. It was suggested that simulation might help employees learn flexible interaction and mutual appreciation. Some of the ideas for simulation education were:

"addressing tricky situations"

"Some advice on how to discuss practices among the staff members. So that we learn to speak our mind and deal with the issues without fighting."

"New dialogical ways of doing the daily work. Solutions for potential problems.”

According to the respondents, simulation coaching might be useful for developing their advising and counseling skills with challenging client groups. For example, a simulated scenario could be used to practice entering a young person's thinking world to help find ways to counsel the client. Reaching a more client-centered approach in counseling was mentioned as a learning need. This is a quote from one respondent:

"I believe that simulation coaching can help enter a young person's thinking world, put oneself in the young person's role - that way it is easier to get an idea of various behavioral disorders and to counsel the young people."

Better client service skills was another learning need mentioned by the respondents in this study. They felt that it was important to learn how to make their clients satisfied with the services provided. Simulated scenarios with dialogical interaction situations were proposed to practice placing oneself in another person's position. Respondents expressed these ideas in the following words, among others:

"How to make clients more satisfied, ability to be present."

"More information about the services available for our clients and about how they develop, new co-operation partners."

Respondents suggested scenarios designed to improve emotional intelligence, situational sensitivity and empathy. Older clients' residential homes, where people are cared for until their death, were especially mentioned in this context. Staff in these homes reported a need to develop their skills in em- pathy and presence, to be able to support both the clients and family members. Similarly, staff in child protection services expressed a need to improve their situational sensitivity and emotional intelligence. They wished that they could use simulation to prepare for the ethically challenging situations that they encountered in their work. They said,

"Learning situational sensitivity, tools how to deal with challenging situations.”

"Emotional intelligence, improving empathy and skills that you need to deal with various challenges in a child protection unit. Aggressive young people/parents, how to support a young person dealing with painful issues."

"More situational sensitivity and means how to find ethical solutions in violent situations."

Ability to act in a logical way in a variety of situations was also mentioned as a learning need that might be met by simulation coaching. Respondents felt the need to construct their own logic to prepare for infrequent situations. Simulation, followed by a debriefing session, could be used to establish a logic and order of action. In the respondents' own words:

"Even if something went wrong in the simulation, it could still help create a logical thinking model, because even then, you reflect on the causes and consequences."

"Life is not always a textbook performance, so you should always be smart enough to look for a cause and consequence, so that you can act in a sensible manner."

Some recently graduated respondents with little experience of care work experienced a need to train what they called "clinical hands-on" skills. On the other hand, according to some more experienced respondents, so much time had passed since their graduation that some changes had occurred in the care methods. These respondents also reported a need to practice clinical skills and practical interventions. The following quote is from the first group mentioned above:

"I just graduated as a practical nurse and I need some confdence and practical skills for everyday work, clinical handson skills."

The need to learn safe and ergonomic techniques mostly emerged in enterprises that offered residential services for older people. The work was physically demanding, so particular attention had to be paid to safety and ergonomics. The staff in these enterprises were well aware of the importance of ergonomics, but felt that during their studies they had not been adequately trained in patient lifting and transfers. Their wishes included the following:

"The right grip to lift and move patients, prevention of back 
problems."

"Technology and other things in nursing have changed a lot. I would like to learn safe practices and tools for various situations."

High quality documentation was also among the learning needs listed by the respondents. Documentation was seen as a factor that promoted safety and continuity of the care. Scenarios with various helping situations and consequent documentation were suggested. Challenging child protection situations were mentioned especially. To quote the respondents,

"We need scenarios where something unexpected happens. And then we should practice how to document it. For example, somebody falls and complains of pain in the hip, how to act and document correctly."

"Some situation that illustrates the Child Protection Act, how to apply the Act, what should one document."

The development of information technology skills was important for social and healthcare staff working in small and middle-sized enterprises because of their needs to communicate effectively, document essential client information and market the services. Respondents worried that they would be left behind, unless they were offered some training on how to exploit the potential of the new digital technology. They said, for example,

"The competence that you need to make the digital leap.,

"The computer skills that you need to give digital counseling if needed."

"... the use of technology and improving the information technology skills in general."

\subsection{Multiprofessional collaboration}

Respondents further mentioned the need to understand the roles, tasks and responsibilities of their colleagues. They said that being better informed might lead to smoother cooperation. One of the respondents, for example, explained,

"Since I have a degree in social services, I wish I could have some multiprofessional simulation training, even to learn more about the challenges in the residents' medication."

Learning new practices to improve clinical action was considered important for several reasons. Respondents wanted to ensure that their work ran smoothly, but they were also interested in the development of co-operation and patient safety. Simulation coaching was regarded as a good opportunity to learn new practices and protocols through a combination of action and discussion. Respondents said, for example,

Published by Sciedu Press
"The correct practice or protocol in various situations, how you should act."

"Action-based learning with help of a scenario helps you remember the new practice, for example the ABCD protocol, which we practiced in the first simulation coaching session."

According to the respondents, respect for common rules should be taken up in the training. Since the training can be tailored to meet the needs of individual enterprises, creation of common rules could be one objective in a scenario. This could be accomplished by presenting ethically challenging situations in the simulations. To quote a respondent:

"Good new rules for the enterprise, where the strong always rule over the more quiet ones, ethical scenarios."

\subsection{Development of the business}

According to the respondents in this study, gaining knowledge on how to improve the competitiveness of their business was important, because small and middle-sized enterprises had to compete with larger organizations. Knowledge about new practices and about the current reform of the health and social services in Finland were mentioned as examples. Keeping up-to-date with changes in society and with the effect of these changes on client work was considered essential for the development of competitiveness. The following quotes illustrate respondents' thoughts:

"I hope that in my business something new will be born as a result of this project."

"My determination is strong, learning will develop and motivate you and insight/creativity promotes learning. The idea that our employer is now investing on developing the competence in the organization, it is an investment in future at many levels and will return to us as a benefit."

Using the social media in marketing and dissemination of information was one of the topics suggested for simulation coaching. The ability to use various channels of social media was considered important for marketing, but also for gleaning ideas on how to develop the business. This was experienced both as a personal learning need and as a general development goal in the organization. A respondent said,

"I want to learn marketing and how to use the social media."

\subsection{Networking between enterprises}

Finally, respondents brought up the importance of networking, which involved benchmarking skills and learning from peers in other enterprises. It was suggested that simulation training should partly take place at the enterprises, so that the participants could learn from each other's practices in concrete terms. Networking was considered a method of 
developing one's enterprise. Respondents pointed out that they seldom had an opportunity to take part in continuing education programs, so they welcomed the possibility to share practices during the multiprofessional simulation coaching project. The quotes below represent this category of learning needs.

"Joint simulations for staff of various enterprises, opportunities for benchmarking."

"I hope that our enterprise will develop now that we have joined the project. You can get some hints from people who represent different walks of life."

\section{Discussion}

This study reveals the theoretical and practical learning needs reported by social healthcare staff in twenty small and middle-sized enterprises in Finland. Respondents seemed to be aware of their need to develop both personally in the area of key competences, and collaboratively in the organization. Most learning needs in this sample seem to concern the respondents' professional skill base. This is a promising result for the ongoing project, since simulation-based learning can be successfully applied in the acquisition of both technical and non-technical skills. ${ }^{[21,22]}$

According to the respondents, their theoretical knowledge base should be expanded and updated in medication administration, acute and prolonged care situations and in the use of scientific knowledge. The finding is supported by the statistical analysis, which revealed poor self-rated theoretical and practical competence in acute situations. Respondents further reported that their practical competence, or professional skill base required strengthening in the areas of interaction and teamwork skills, and advising and counseling skills, among others. The statistical analysis also disclosed that respondents found it difficult to identify factors, which influenced group dynamics. Similar results have been reported earlier in studies on healthcare staff's simulation learning needs. In these studies, too, respondents experienced a need to consolidate both their theoretical and practical competence and stressed the importance of communication, counseling skills and multiprofessional collaboration. ${ }^{[16,36]}$ The respondents in this study also mentioned situational sensitivity, empathy and problem-solving skills.

It has been proposed that multiprofessional communication and interaction, identified in this study as one area in need of improvement, could be practiced using multiprofessional simulation education. Learning together in simulated situations can increase participants' understanding of each other's professional roles and tasks, which can result in smoother collaboration and better quality of client service. ${ }^{[17,18]} \mathrm{Col}-$ laboration between professionals is only possible if the various professional groups take each other in consideration and commit themselves to sharing knowledge and, when necessary for the optimum client service, to crossing traditional organizational boundaries. ${ }^{[8,37]}$ Lacking interaction and information flow among social and healthcare staff has been found to be a hindrance to holistic encounters with clients. ${ }^{[38]}$

It could be suggested based on the results of this study that simulation-based coaching could help enhance commitment to multiprofessional collaboration by creating a common language for the participants through dialogical learning. A body of research confirms the importance of open interaction ${ }^{[39,40]}$ and conflict resolution and negotiation skills ${ }^{[41]}$ when building up multiprofessional collaboration. This means that ideally, professionals should be skilled in debate and dialogue and prepared to negotiate flexible roles and responsibilities. ${ }^{[42]}$

Besides examining respondents' personal learning needs, the results of this study can also be looked at from the perspective of developing the working communities, or the enterprises. The staff members' responses covered the categories of multiprofessional collaboration, development of the business and networking. The results are reminiscent of a model of expertise proposed by Helakorpi. ${ }^{[43]}$ In the model, expertise is thought to consist of the individual's core competence, working community competence and development competence, which involves the development of one's own competence (metacompetence) and the development of one's field and the world of work (strategic competence). For example, the fact that respondents expressed a need to learn how to seek and apply evidence-based knowledge, is an indication of their motivation to develop professional competence and clinical expertise. ${ }^{[12]}$ Looked at from the perspective of the social and healthcare enterprises, the results of this study contain collaboration and development challenges that are of importance to the whole society. Closer contacts between educational institutions and enterprises is one of these challenges. The same objective has been set for the current educational reform in Finland; working life is becoming increasingly more important as a learning environment, and this trend is likely to grow stronger in future. The simulation coaching project described in this article is an example of services tailored for the needs of the organizations. The project can increase the range of products - service models and training - offered by the educational institutions involved. The finished products can be offered as chargeable services.

\section{Conclusions}

As confirmed by this study, social and health care staff in small and middle-sized enterprises require simulation-based 
training that promotes multiprofessional collaboration both in acute, recurrent and infrequent situations. At the same time, the staff need to develop communication for situations in which interdisciplinary teamwork is essential. Learning to identify factors that affect group dynamics is one of the skills that could be practiced with help of simulation. Simulation pedagogy can also be used to prepare for demanding client and family counseling sessions requiring situational sensitivity and problem-solving skills.

The results of this study will be used when planning multiprofessional simulation-based coaching for and together with social and healthcare staff in small and middle-sized enterprises. They can also be useful nationally and internationally when planning and providing similar simulation-based training. The concepts and results of the study can be employed in medical, nursing and social work research on simulationbased learning.
In addition, the results can be useful as tools for selfreflection, when staff members want to look at their professional strengths and development needs. The results can simultaneously function as a starting point for shared reflection and development efforts at the enterprises. As the study provides an overview of the situation in the SME sector, the results may benefit political decision-making and potentially strengthen the role of small and middle-sized enterprises in the provision of social and healthcare services. Offering simulation-based training in the facilities of small and middle-sized enterprises is a novelty both nationally and internationally and could increase the number of participants and promote their motivation and interest in sharing new information.

\section{Conflicts of InTERest Disclosure}

The authors declare they have no conflicts of interest.

\section{REFERENCES}

[1] European Union Health Programme 2014-2020. Available from: https://ec. europa.eu/health/programme/policy/201 4-2020_en

[2] Sosiaali- ja terveysministeriö [The Ministry of Social Affairs and Health in Finland]. Laatusuositus hyvän ikääntymisen turvaamiseksi ja palvelujen parantamiseksi 2017-2019 [Quality recommendation to guarantee a good quality of life and improved services for older persons 2017-19. In Finnish]. Sosiaali- ja terveysministeriön julkaisuja. Sosiaali- ja terveysministeriö ja Suomen Kuntaliitto. Helsinki. 2017; 6. Available from: http://urn.fi/URN : ISBN : 978-952-0 0-3960-8

[3] Työ- ja elinkeinoministeriö [Ministry of Economic Affairs and Employment in Finland]. Hyvinvointialan työ- ja elinkeinopoliittinen kehittäminen - HYVÄ. HYVÄ-OHJELMA 2011-2015 [Development of the economy and employment in welfare industry. Development Project 2011-2015. In Finnish]. 2013. Available from: http: //docplayer.fi/2203034-Hyva-ohjelma-2011-2015.html

[4] European Commission. The new SME definition. User guide and model declaration. 2005. Available from: www. eusmecentre.org.cn/sites/default/files/fil es/news/SME\%20Definition.pdf

[5] Federation of Finnish Enterprises. Available from: https: //www.yrittajat.fi/en/about-federation-finnish-ent erprises/small-and-medium-sized-enterprises-526261

[6] Weller JM, Barrow M, Gasquoine S. Interprofessional collaboration among junior doctors and nurses in the hospital setting. Med Educ. 2011; 45(5): 478-87. PMid: 21414024. https://doi.org/10.1 $111 / j .1365-2923.2010 .03919 \cdot x$

[7] Tuomela K, Heikkilä K, Haapanen H, et al. Moniammatillinen oppiminen yhteistyöosaamisen edistäjänä terveydenhuollossa [Interprofessional education promotes collaboration competence in health care. In Finnish, with English abstract]. Hoitotiede [Journal of Nursing Science]. 2017; 29(4): 264-75.

[8] Payne M. Teamwork in multiprofessional care. New York: Palgrave; 2000.

Published by Sciedu Press
[9] Eriksson E, Korhonen T, Merasto M, et al. Sairaanhoitajan ammatillinen osaaminen. Sairaanhoitajakoulutuksen tulevaisuus -hanke [The nurse's professional competence. Future of nursing education project. In Finnish]. Ammattikorkeakoulujen terveysalan verkosto ja Suomen sairaanhoitajaliitto ry [Universities of Applied Sciences' Health Network and the Finnish Nurses Association]. Porvoo: Bookwell Oy; 2015.

[10] Hanhinen T. Työelämäosaaminen: Kvalifikaatioiden luokitusjärjestelmän konstruointi [Working life skills and knowledge: the Construction of the qualification classification system. In Finnish, with English abstract. Dissertation]. University of Tampere; 2010. Available from: http://acta.uta.fi/pdf/978-951-44-8290-8.p df

[11] Helakorpi S. Osaaminen ja sen tunnistaminen työelämän ja koulutuksen yhteisenä haasteena [Recognition of learning as a common challenge for practice and education. In Finnish]. Ammattikorkeakoulujen verkkojulkaisu. UAS Journal. 2009. Available from: https://arkisto.uasjournal.fi/osaaja_2009-4/H elakorpi\%20PDF.pdf

[12] Sosiaali- ja Terveysministeriö [The Ministry of Social Affairs and Health in Finland]. Koulutuksella osaamista asiakaskeskeisiin ja moniammatillisiin palveluihin. Ehdotukset hoitotyön toimintaohjelman pohjalta [Developing competence for client-centered and multiprofessional services through education. in Finnish]. Reports and Memorandums of the Ministry of Social Affairs and Health in Finland. 2012.

[13] Hakkarainen K. Kollektiivinen älykkyys [Collective intelligence. In Finnish, with English abstract]. Department of Psychology. University of Helsinki. 2006. Available from: http://www.tml.tkk.fi/Opinnot/T110.556/2004/Mater iaali/kollektiivinenalykkyys.pdf

[14] Boyd AM, Jackson ML. An effective model for rapid skills acquisition through a simulation-based integrated learning environment. J Educ Comput Res. 2004; 30(1\&2): 1-21. https ://doi . org/10.2 190/E8CN-91GX-R6WA-Y05N 
[15] Jacobs BL. Teaching and learning negotiation in a simulated environment. Widerer L J. 2008; 18: 91-112.

[16] Salminen-Tuomaala M, Rouvala C, Sankelo M, et al. Hoitohenkilökunnan ja lääkäreiden kokemuksia simulaatio-opetuksen tarpeista [Nursing and medical staff's experienced simulation training needs, in Finnish with English abstract]. Accepted for publication in Hoitotiede [Journal of Nursing Science]. 4 Dec 2017.

[17] Miller A, Morton S, Sloan P, et al. Can a single brief intervention improve participants' readiness for interprofessional learning? J Interprof Care. 2013; 27(6): 532-3. PMid: 23802734. https : //doi.org/10.3109/13561820.2013.805736

[18] Salminen-Tuomaala M, Jaskari P, Perälä S, et al. Nursing and medical staff's experiences of simulation education. Clin Nurs Stud. 2017; 5(4): 73-80. https : //doi .org/10.5430/cns . v5n4p73

[19] Hansen J, Bratt M. Competence acquisition using simulated learning experiences: a concept analysis. Nurs Educ Perspect. 2015; 36(2): 102-7. PMid: 29194134. https://doi .org/10.5480/13-1198

[20] Cooper S, Cant R, Porter J, et al. Simulation based learning in midwifery education: a systematic review. Women Birth. 2012; 25(2): 64-78. PMid: 21489894. https ://doi.org/10.1016/j . wombi. 2011.03 .004

[21] March AL, Adams MH, Robinson C. Student characteristics and perceptions of learning and confidence acquisition associated with simulation. Nurs Educ Perspect. 2014; 35(5): 335-6. PMid: 25291932. https://doi.org/10.5480/12-998.1

[22] Dieckmann P, Patterson M, Lahlou S, et al. Variation and adaptation: learning from success in patient safety-oriented simulation training. Adv Simul. 2016; 2(21): 1-14.

[23] Issenberg SB, Mcgaghic WC, Petrusa ER, et al. Features and uses of high-fidelity medical simulations that lead to effective learning: a BEME systematic review. Med Teach. 2005; 27: 10-28. PMid: 16147767. https ://doi.org/10.1080/01421590500046924

[24] Duff B. Creating a culture of safety by coaching clinicians to competence. Nurse Educ Today. 2013; 33(10): 1108-11. PMid: 22726347 https://doi.org/10.1016/j.nedt.2012.05.025

[25] Forneris SG, Neal DO, Tiffany J, et al. Enhancing clinical reasoning through simulation debriefing: a multisite study. Nurs Educ Perspect. 2015; 36(5): 304-10. PMid: 26521499. https ://doi.org/10.5 480/15-1672

[26] Jeffries PR. Signs of maturity. Simulations are growing and getting more attention. Nurs Educ Perspect. 2015; 36(6): 358-9. https : //doi.org/10.5480/1536-5026-36.6.358

[27] Aaltola E, Keto S. Empatia. Myötäelämisen tiede [The science of empathy. In Finnish]. Helsinki, Finland: Into Kustannus Oy; 2017.

[28] Buckley S, Hensman M, Thomas S, et al. Developing interprofessional simulation in the undergraduate setting: experience with five different professional groups. J Interprof Care. 2012; 26(5): 362-9. PMid: 22594349. https ://doi.org/10.3109/13561820.2012. 685993
[29] Heikkilä T. Tilastollinen tutkimus [Statistical research. In Finnish]. 9ren. ed. Helsinki: Edita Publishing Oy; 2014.

[30] Graneheim UH, Lundman B. Qualitative content analysis in nursing research: concepts, procedures and measures to achieve trustworthiness. Nurse Educ today. 2004; 24(2): 105-12. PMid: 14769454. https://doi.org/10.1016/j.nedt.2003.10.001

[31] TENK Finnish Advisory Board on Research Integrity Responsible conduct of research and procedures for handling allegations of misconduct in Finland. 2012. [In Finnish, Swedish and English]. Available from: http://www.tenk.fi/files/HTK_ohje_2013.pdf

[32] Burns N, Grove S. The practice of nursing research. Appraisal, synthesis and generation of evidence. 6th ed. Missouri: Saunders Elsevier, Missouri; 2009.

[33] Lincoln YS, Cuba EG. Naturalistic inquiry. Newbury Park. CA: Sage Publications; 1985.

[34] Hamilton MB. Online survey response rates and times: background and guidance for industry. J Travel Res. 2003; 49(1): 121-35.

[35] Holloway I, Wheeler S. Qualitative research in nursing and healthcare. 3rd ed. West Sussex: Wiley-Blackwell; 2010.

[36] Hallikainen J, Väisänen O. Simulaatio-opetus ensihoidossa [Simulation training in emergency care. In Finnish]. Finnanest [Journal of the Finnish Society of Anaesthesiologists]. 2007; 40(5): 436-9.

[37] Kenny G. The importance of nursing values in interprofessional collaboration. Br J Nurs. 2002; 1: 65-8. PMid: 11826322. https : //doi.org/10.12968/bjon.2002.11.1.9328

[38] Jolanki O, Tynkkynen LK, Sinervo T. Professionals' views on integrated care. J Integr Care. 2017; 25(4): 247-55. https : //doi .or g/10.1108/JICA-06-2017-0018

[39] D'Amour D, Oandasan I. Interprofessionality as the field of interprofessional practice and interprofessional education: an emerging concept. J Interprof Care. 2005; 19: 8-20. PMid: 16096142. https ://doi.org/10.1080/13561820500081604

[40] Kvarnström S. Difficulties in collaboration: a critical incident study of interprofessional healthcare teamwork. J Interprof Care. 2008; 22 : 191-203. PMid: 18320453. https ://doi.org/10.1080/135618 20701760600

[41] Hall P. Interprofessional teamwork: professional cultures as barriers. J Interprof Care. 2005; 19: 188-96. PMid: 16096155. https : //doi.org/10.1080/13561820500081745

[42] Isoherranen K. Uhka vai mahdollisuus - moniammatillista yhteistyötä kehittämässä [Threat of possibility - developing interprofessional collaboration. In Finnish, with English abstract. Dissertation]. Sosiaalitieteiden laitoksen julkaisuja. Department of Social Psychology. University of Helsinki; 2012.

[43] Helakorpi S. Koulutuksen kehittävä arviointi. Työkaluja osaamisen johtamiseen [Evaluation and development in education. Tools for knowledge management. In Finnish]. Häme University of Applied Sciences. Ammatillisen opettajakorkeakoulun julkaisuja. 2006. 